\section{Colonial scientific- medical documentary films and the legitimization of an ideal state in post-war Spain}

\author{
Documentários médico- \\ científicos coloniais e a \\ legitimação de um estado \\ ideal na Espanha pós-guerra
}

Carlos Tabernero

Professor, Centre for the History of Science (CEHIC)/ Faculty of Medicine/Universitat Autònoma de Barcelona. Research Module C Carrer de Can Magrans, s.n. 08193 - Barcelona - Spain

carlos.tabernero@uab.cat

Isabel Jiménez-Lucena

Professor, History of Science Studies/Faculty of Medicine/ University of Malaga/Campus de Teatinos.

Bulevar Louis Pasteur, 32

29071 - Málaga - Spain

isajimenez@uma.es

Jorge Molero-Mesa

Professor, CEHIC/Faculty of Medicine/

Universitat Autònoma de Barcelona. Research Module C

Carrer de Can Magrans, s.n.

08193 - Barcelona - Spain

jorge.molero@uab.cat

Recebido para publicação em fevereiro de 2015.

Aprovado para publicação em julho de 2015.
TABERNERO, Carlos; JIMÉNEZ-LUCENA, Isabel; MOLERO-MESA, Jorge. Colonial scientific-medical documentary films and the legitimization of an ideal state in post-war Spain. História, Ciências, Saúde - Manguinhos, Rio de Janeiro, v.24, n.2, abr.-jun. 2017, p.349-369.

\section{Abstract}

This paper explores the role of film and medical-health practices and discourses in the building and legitimating strategies of Franco's fascist regime in Spain. The analysis of five medical-colonial documentary films produced during the 1940s explores the relationship between mass media communication practices and technoscientific knowledge production, circulation and management processes. These films portray a non-problematic colonial space where social order is articulated through scientific-medical practices and discourses that match the regime's need to consolidate and legitimize itself while asserting the inclusion-exclusion dynamics involved in the definition of social prototypes through processes of medicalization.

Keywords: medical-colonial films; Franco's regime; inclusion-exclusion; scientific discourse; medicalization.

\section{Resumo}

$O$ artigo explora o papel de práticas e discursos em saúde e cinema na construção e legitimação das estratégias do regime fascista de Franco na Espanha. A análise de cinco documentários médicos coloniais produzidos na década de 1940 explora a relação entre as práticas de comunicação de massa e os processos de produção, circulação e administração do conhecimento técnicocientífico. Tais filmes retratam um espaço colonial não problemático onde a ordem social é articulada por meio de práticas e discursos médico-científicos que atendem à necessidade de consolidar e legitimar o regime, validando a dinâmica de inclusãoexclusão envolvida na representação de protótipos sociais por meio de processos de medicalização.

Palavras-chave: filmes médicos coloniais; regime franquista; inclusão-exclusão; discurso científico; medicalização. 


\section{Film, medicine and the empire: medical-colonial documentaries in post-war Spain}

In 1944, the General Director of Morocco and the Colonies during the early Franco regime in Spain, General José Díaz de Villegas, requested Manuel Hernández Sanjuán, co-founder of Hermic Films, to produce "documentary films about the Guinean colony, with the aim of showing Spain the job that was being done" (F.-Fígares, 2003, p.234; Ortín, Pereiró, 2006). The result was 31 documentary films produced between 1944 and 1946 (the Equatorial Guinea series) classified under seven thematic clusters: Woodland resources, The ethnology inhabitants, Wildlife and natural phenomena, The work of missionaries and education, Development and technology, Military exaltation, and Tropical diseases and health. Three of the films analyzed in this paper - Médicos coloniales (Colonial physicians), Los enfermos de Mikomeseng (The sick people of Mikomeseng; henceforth Mikomeseng), and Fiebre amarilla (Yellow fever) ${ }^{1}$ - are from the latter cluster and were directed by Hernández Sanjuán in 1946. ${ }^{2}$ The other two - Enfermos en Ben-Karrich (Sick people at Ben-Karrich; henceforth Ben-Karrich) and Médicos en Marruecos (Physicians in Morocco) ${ }^{3}$ - set in the Spanish protectorate in Morocco, were directed in 1949 by the physician Santos Núñez, who had also been a scriptwriter for Sanjuán's Equatorial Guinea series films and for other documentaries previously shot in Morocco and the Sahara.

This series of documentary films effectively reveals the regime's special interest in cinema as a propaganda tool and its deliberate use of colonial settings as legitimating instruments. Indeed, the strong link between a nascent production company like Hermic Films and colonial projects in Guinea and in the protectorate in Morocco illustrates the potentiality of an officially sanctioned market for this kind of product during the early years of Franco's rule. Interestingly, the thematic clusters of the government-sponsored Equatorial Guinea series show a markedly techno-scientific trait: science, medicine and technology (wildlife, ethnology, medical-health issues, and resources) are the core themes, along with religion, education, discipline and control (missionaries and the military). The fact that medical-health issues are the focus of one of the thematic clusters is also indicative of the importance of this particular set of practices and discourses within the propaganda and legitimation strategies employed by the regime.

Through the analysis and careful historical contextualization of these five films, this paper examines the combined role of media and medical-health practices and discourses in the building and legitimating strategies of Franco's fascist regime in its first decade. In particular, we look at the bearing of film and medicine-health on the efforts of consolidation of such a distinct twentieth century socio-political regime. Our preliminary goal is to examine the characteristics of the openly vertical flow of information during the Franco regime. We focus on the use of the mass media, particularly in connection with medicalhealth issues and colonial rule. Upon discovering these five films after probing the Spanish Film Archive, we realized that their combined medical and colonial content provide a remarkable opportunity to explore the multidimensional linkages between the mass media and scientific, medical and technological knowledge management. Certain key questions arose concerning a context in which the indoctrination of the population of both the colonies and metropolitan center was crucial for the building of the new regime: how were 
scientific-medical knowledge generation and management portrayed in the films? What was the link between the way scientific-medical knowledge generation and management were depicted and the need to consolidate and legitimize the Franco regime in its early stages? What was the role of the different actors (the colonizers and colonized people portrayed in the documentaries, the administrators of the regime, filmmakers and target audience) in making of these documentary films? And, bearing in mind our concern with the link between scientific knowledge management and the strategies employed to build and legitimize the regime, what was the nature of the relationships between the different social groups that were socially, professionally and epistemologically articulated in, through and around these films?

\section{Power, education and everyday life: inclusion-exclusion dynamics and the management of scientific-medical knowledge through film communication practices}

To address these questions, we first drew on recent developments in the fields of social and historical studies of science, which broadly consider science as a form of communication and a practical, multilayered everyday activity (Secord, 2004; Topham, 2009). This helps to establish meaningful analytical correlations between diverse scientific and media processes. It also implies taking into consideration the appraisal, adoption, use and modification of specific sets of techno-scientific and mass media practices and discourses by the actors involved according to their individual needs, beliefs and attitudes. To take into account all parties involved in making and consuming the films analyzed in this paper - i.e., government sponsors, filmmakers and viewers - we also need to draw on practice theory as applied to media. Considering media as practice affords the exploration of routine contexts of production, circulation and appropriation as specific settings of empirical interest within which processes of power and the nature of authority can be explored (Couldry, 2003, 2004; Bräuchler, Postill, 2010). Indeed, the combination of these two analytical frameworks (i.e., science as communication and media as practice) and the fact that they focus on everyday contexts and routines to explore knowledge management strategies help us to consider the epistemic agency of the actors involved in the communication practices that comprise the inception, development and consumption of these films. Furthermore, it also relates these practices and discourses to wide-ranging social and cultural embodiment and tensions of everyday life (Tabernero et al., 2009; Tabernero, Jiménez-Lucena, Molero-Mesa, 2012, 2013; Florensa, Hochadel, Tabernero, 2014).

We argue that these documentary films, primarily through their medical-health content and the colonial setting, depict the construction of an allegedly ideal form of social and political organization. In this sense, we also consider the role of film in the creation of diegetic techno-scientific prototypes pertaining to social, political, ideological and cultural structures (Kirby, 2008, 2010; Jiménez-Lucena, 2011; Tabernero, Jiménez-Lucena, Molero-Mesa, 2012). Given the combined medical and colonial content of the films analyzed in this paper, we ponder the role of the mass media in relation to scientific-medical knowledge management in colonial contexts. It has been shown that the application of medical-health knowledge is conducive to the establishment of clear-cut differences between colonizers and the colonized 
(Molero-Mesa, 2003; Jiménez-Lucena, 2006; Medina-Doménech, 2003, 2009; Kusiak, 2010). Within these contexts, power relations were articulated around medical science's normative and normalizing capacity to define health and disease. This in turn involved discrediting indigenous knowledge to impose the colonizers' superiority (Molero-Mesa, 2006; Mignolo, 2000; Memmi, 1991). Accordingly, with respect to the circulation and application of medicalhealth knowledge, the approach was opportunely utilitarian and relied on the supposed incommensurability of techno-scientific knowledge as a neutral and inaccessible (for nonexperts) source of wealth and organization (Irwin, Wynne, 1996; Bensaude-Vincent, 2001; Nieto-Galán, 2011; Horst, Michael, 2011; Tabernero, Jiménez-Lucena, Molero-Mesa, 2012; Tabernero, Perdiguero, 2015). In such contexts, as it has been argued, the mass media medical-health content was generated as a "political instrument to promote [a] model of society." Images of reality were produced for the rulers' benefit with the aim of "teaching the population at large how to live, [through the diffusion of] social and political behaviors [and] specific attitudes and values" (Jiménez-Lucena, Ruiz-Somavilla, Castellano-Guerrero, 2002, p.203). Medical-health and media experts would then be "the" necessary source of immediate solutions (in this case, health, information, education and entertainment). At the other end of the spectrum, purportedly nonparticipant, submissive and dependent nonexperts would be helped with their most pressing everyday problems (disease, epidemics) and needs (the articulation of a symbolic framework and the organization of time and space within which social life would develop). Eventually, the social order conveyed by the media (through form and content) would not only be seen as socio-politically and technoscientifically viable and needed, but also as the fulfilment of a widespread socio-culturally self-assured routine (Giddens, 1984).

With respect to enculturation, films and other forms of media act as a powerful virtual witnessing technology for such prototypical socio-political models (Kirby, 2008, 2010). In this sense, it is essential to consider that the use and consumption of films may be understood as a set of practices that significantly influence people's social, communication and working skills. Moreover, films are essential elements of the social and space-time structure of people's everyday lives, where all actors involved (in the production and consumption of knowledge) contribute in one way or another to the processes of validation of that particular knowledge and the associated authority systems. All this implies that the mass media may be considered unofficial learning spaces where meaningful processes of generation, circulation and management of knowledge occur (Thompson, 1995; Tabernero et al., 2009; Tabernero, Jiménez-Lucena, Molero-Mesa, 2012, 2013). Bearing this in mind, we deemed it necessary to extend our analysis into the field of the dynamics of inclusion and exclusion in order to explore the evidently disciplining representation of colonial medical-health practices in the films (Bohn, 2009; Rawal, 2008; Luhmann, 1998), thus allowing us to further address the complexity of the power relations. In this respect, social inclusion and exclusion are seen as simultaneous and not necessarily opposing processes, a continuum of interwoven practices and discourses (Molero-Mesa, JiménezLucena, 2013; Tabernero, Jiménez-Lucena, Molero-Mesa, 2013). A binary, antagonistic view of these two concepts hampers comprehension of the differences between groups and the mechanisms involved in establishing and maintaining them. Based on this 
premise, and considering that biopower has been considered a sophisticated instrument of social control, medical-health knowledge management is also viewed as playing an essential role in social inclusion and exclusion processes (Foucault, 2005). In this sense, the distinction between inclusion and exclusion is consequently made in functional (scientificmedical) terms and remains internal to the system. The modern concept of health had huge political potential since medical science was able to provide a scientific definition that disregards the social and environmental causes of disease. Medicine thus became a discipline that promotes social reform as it was able to intervene in social problems as a normalizing authority. Thus, inclusion and exclusion are not differentiated merely by the physical separation of individuals, as proposed by theories of deviance. Instead, the distinction is made by establishing carefully crafted, supervised and controlled distances, or including exclusion, as sustained by societal differentiation theories (Bohn, 2009; Foucault, 1982; Luhmann, 1998). Moreover, these distances are suitably conveyed by media communication practices. In our case, the analysis of the power relations related to the films studied by this paper is inevitably linked to precise medicalization (Ballard, Elston, 2005; Jiménez-Lucena, Molero-Mesa, 2011; Bonah, Laukötter, Cantor, 2011; Ostherr, 2013; Tabernero, Perdiguero, 2015) and propaganda strategies (MacKenzie, 1986; Lynch, 2000; Molero-Mesa, 2001; Jiménez-Lucena, Ruiz-Somavilla, Castellano-Guerrero, 2002; Medina-Doménech, Menéndez-Navarro, 2005; Boon, 2005; Perdiguero, Ballester, Castejón, 2007; Caprotti, 2009; Stanard, 2009; Kusiak, 2010).

In what follows, we argue that the documentary films we analyze presented the regime's disciplining project through the embedding of techno-scientific practices and discourses (mass media and medical-health) in people's everyday lives. Moreover, we argue that the films's rendering of social relations, as established around medical-health practices and discourses, amounts to the representation of a distinct excluding inclusion strategy which was part of a timely (for Franco's regime) portrayal of a prototypical state. This analysis also allows an in-depth examination of the main links between techno-scientific knowledge management and key power dynamics.

We start with a description of the historical circumstances that led to the socio-political exploitation of the normative management of techno-scientific knowledge during the Franco regime as a powerful indoctrination device. In this respect, we also explore the regime's use of cinema, particularly documentary films, as an unofficial educational space and its most effective device. The following sections analyze the technical and narrative characteristics of the five documentary films related to the portrayal of distinct social groups (according to race, class and gender) across the boundary of techno-scientific knowledge production and management. Finally, we discuss how, through the portrayal of medical-health activities in colonial contexts, these films articulated a carefully crafted social excluding inclusion dynamics that was essential to the regime's building and legitimating efforts. By characterizing the portrayal of medical-health activities in colonial settings, this paper attempts to contribute to the historical understanding of the socio-political role played by the media and medicalhealth practices and discourses in contemporary society. 


\section{The need and opportunity for film and medical-health discourses and practices in Franco's post-war Spain}

At the end of the Spanish Civil War (1936-1939), Franco and his supporters were faced with the challenge of establishing and consolidating a new regime and the task of building a social, economic and administrative structure that would ensure the survival of a country immersed in chaos after three years of devastating war. This would be achieved in accordance with the regime's need for political, ideological and cultural legitimization, compulsorily at home and rather more awkwardly abroad. This complex process took place within a context of increasing international isolation, leading to an autarchic regime in the early years that adopted a multidimensional, strong-arm approach. The regime was built within a context of grueling widespread poverty, starvation and epidemics, isolation, and a conspicuous shortage of resources (Preston, 1994; Del Cura, Huertas, 2007).

The efficient indoctrination of "the people" was essential. The regime's discourse focused primarily on the justification of a repressive, unwavering and enduring system, built around the paternalistic figure of El Caudillo. It also aimed to dispense with all vestiges or signs of the republican period, mainly through employing social and historical decontextualization strategies. The regime focused on generating representations of a kind of timeless essentialism as effective tools for building a national identity detached from both the republican past and the outside world (Medina-Doménech, Menéndez-Navarro, 2005; Monterde, 2004). This was achieved through the construction of a socio-political project: national syndicalism. This project was based on structuring knowledge management in strictly asymmetrical, unidirectional flows of information, "focusing on attaining positive attitudes of political adherence to the ruling forces and submission and obedience to the experts" (Jiménez-Lucena, Ruiz-Somavilla, Castellano-Guerrero, 2002, p.203).

It is no surprise that the Franco administration regarded mass media and medical-health practices and discourses as the primary means of building the regime's social, ideological, and political foundations. These two sets of practices and discourses revolve around strategic knowledge management in contemporary society, whether totalitarian or not (Lynch, 2000; Boon, 2005; Bonah, Laukötter, Cantor, 2011; Ostherr, 2013; Tabernero, Perdiguero, 2011, 2015). Given the arduous post-war circumstances, medical-health policy was opportunely utilitarian and relied on the allegedly neutral character of techno-scientific knowledge as a source of wealth and progress. In this sense, medical-health knowledge management quickly became a crucial instrument of political control (Jiménez-Lucena, 1994, 1998; JiménezLucena, Ruiz-Somavilla, Castellano-Guerrero, 2002; Molero-Mesa, 1994, 2001; Castejón, Perdiguero-Gil, Ballester, 2006; Castejón, Perdiguero-Gil, Piqueras, 2012; Perdiguero, Ballester, Castejón, 2007).

At the same time, as in other countries not necessarily under totalitarian rule, the Franco regime deemed cinema to be an essential means of enculturation (Ellwood, 1987; RodríguezTranche, Sánchez-Biosca, 2001; Monterde, 2004; Medina-Doménech, Menéndez-Navarro, 2005; Reeves, 1999; Lynch, 2000; Reich, Garofalo, 2002; Caprotti, 2009). Just a few months after the end of the Civil War, the Film Regulatory Subcommittee (Subcomisión Reguladora de la Cinematografía) was created due to cinema's "high significance as material and spiritual 
propaganda" (Spanish Official Newsletter, 2 October 1939; quoted in Taibo, 2002, p.23). Cinema had a notable capacity to influence "the political and cultural configuration of society" by generating apt representations of the regime (Jiménez-Lucena, Ruiz-Somavilla, Castellano-Guerrero, 2002, p.203). Furthermore, and conveniently, it was swiftly becoming "the most popular form of entertainment in Spain in the post-war years" (Medina-Doménech, Menéndez-Navarro, 2005, p.394).

Based on these premises, documentary films as a scientific-technological (i.e., objective) form of cinema, was a particularly apposite device for the regime's indoctrination efforts (Boon, 2008). Such films would promote the necessary virtual witnessing of the viability, necessity, benevolence and normalcy of the situations and processes depicted (Kirby, 2010). As the Franco administration states:

It has become essential to develop a body of documentary films in the service of our propaganda agencies that is able 'to reflect the different aspects of life in our Fatherland in an exact, artistic manner, and using perfect techniques, and educate and instruct our people in a most entertaining and efficient manner' (Regulations for the organization and operation of the official body for cinematographic production, edition and distribution, NODO, 29 September 1942, quoted in Matud Juristo, may 2008, p.107-108; emphasis added).

The compulsory state-controlled series of cinema newsreels, known as NO-DO (Noticiarios $y$ Documentales), provided information, education and entertainment. The newsreels were a major propaganda instrument and the regime's principal means of generating representations of its imagined nation, providing "Spanish society with new cultural meanings of science, scientists and technology." Hence, the medical-health content of these films was used primarily to legitimize the construction of a new national identity rather than to educate the population about health issues (Medina-Doménech, Menéndez-Navarro, 2005, p.393-394; Ramírez-Martínez, 2006).

\section{Documentary films produced by Manuel Hernández Sanjuán and Santos Núñez}

Sanjuán's and Núñez's documentary films incorporated a third set of practices and discourses related to the colonies. The imperial rhetoric in the early years of the Franco regime focused on social and historical simplification and de-contextualization (Elena, 2001; F.-Fígares, 2003. For comparative purposes, see also: MacKenzie, 1986; Lynch, 2000; Stanard, 2009). It also enabled the portrayal of processes of classification and rationalization of social groups, which were fundamental for consolidating and legitimizing a given social order (Molero-Mesa, 2006; Jiménez-Lucena, 2006; Tabernero, Jiménez-Lucena, Molero-Mesa, 2012). Therefore, official support for the production of colonial documentary films and their aims were unequivocally stated, as was the importance of science and medicine and other defining and legitimating staples of the regime such as religion, education, and the military:

all that is missing is the sweet melody, all indisputable truth, of the most noble heroic deeds of those great Spaniards - missionaries, officials, teachers, 'men of science' - who proclaimed and proclaim in the lands of Africa the religion of Christ, 'the conquests of medicine,' the essences of culture, 'that a man needs to live his time' ... this task well deserves to be shown on screens, as the screens have already shown the war heroism 
that made it possible (Primer Plano 83, 17 October 1942, as quoted in F.-Fígares, 2003, p.234; emphasis added).

Within this context, Sanjuán's and Núñez's documentary films effectively served the regime's enculturation aims. First, the films provided information, as they documented a distant reality from the mother country's point of view. Second, they offered entertainment, whereby a distant and apparently problematic situation was portrayed as exotic and heroic. Finally, they were a source of education, since they portrayed an extensive civilizing drive and its social, political and cultural implications. Within this framework, medical-health practices and discourses were represented as a necessary, heroic, practical and impartial source of construction and organization of a specific kind of society, i.e., the colonies ruled by the Franco regime. This colonial/imperial venture provided a clear representation of the expert-driven, and, as such, supposedly impartial processes of definition and rationalization of distinct social groups.

In order to understand the narrative, argumentative and metaphorical aspects of the films, it is essential to examine the interrelationship between the actors involved in the wide variety of communication practices developed to ensure that these films served the regime's aims and needs. This approach takes simultaneously into account the (medical-health and colonial) discourses and practices conveyed by the films, the associated representations of the spaces and instruments employed, and the people who inhabit and use them (experts and non-experts, the colonizers and the colonized). Although the analysis applies to all five films, for practical reasons we mostly, albeit not exclusively, focus on two: Mikomeseng, as it provides an clear account of the construction of an ideal society through carefully crafted, techno-scientifically-driven practices and discourses; and Ben-Karrich, since, as we shall see, it provides the necessary contrast between the two colonial settings.

To start with, the voice-over replicates the "voice of the One" quality featured by the pieces produced and/or dubbed for the official newsreel (Medina-Doménech, MenéndezNavarro, 2005). Under an informational disguise, the aim was ultimately the de-contextualized glorification and legitimization of the regime. The language combined technical expressions and colloquial phrases for diseases (etiology, prevention, treatment), expertise and technologies, and associated health policies. The insertion of anecdotes aimed to enhance the entertainment value of the films, but was ultimately dismissive of both indigenous knowledge and the viewers' capacity to understand. Technical language was used to describe the use of colancoba against leprosy in Mikomeseng, pleurodesis in Ben-Karrich, and surgical procedures in Physicians in Morocco, while colloquial language was used to describe mycobacterium as "small black rods" in Mikomeseng, and X-rays as "the magic screen" in Ben-Karrich. The technical description of colancoba and the associated lab procedures in Mikomeseng was also combined with a long account of an indigenous legend, thus highlighting the differences between the two types of knowledge. In Colonial physicians, the entire commentary is fundamentally colloquial. However, the clearest example is probably the lengthy account (nearly half of the documentary) of laboratory techniques in Yellow fever, where these types of language are seamlessly blended. Together, these elements embodied the severe, paternalistic and calculatedly quotidian authority of El Caudillo and his regime, and displayed an outwardly expert, practical and unbiased character. 
The representation of medical technologies and facilities provided the required sense of "order, strength and cleanliness" associated with the new state (Medina-Doménech, Menéndez-Navarro, 2005, p.395). However, as opposed to the static objects and empty spaces usually displayed in the official newsreels in the 1940s, these films showed the competence and dependability of the regime by showing the handling of instruments by physicians and technicians and the everyday interaction of medical staff with the many patients housed in the facilities. The leper colony and the tuberculosis sanatorium portrayed in Mikomeseng and Ben-Karrich, respectively, were ostensibly described by showing constant contact between physicians, technicians and patients. In Physicians in Morocco, apart from the home visit of a rural doctor to a patient, there was a lengthy description of the routine operations of rural dispensaries, a polyclinic and a hospital. Waiting rooms, corridors and wards were literally swarming with patients. An array of appointments (from general medicine to dentistry and ophthalmology) was shown, together with procedures leading up to patient surgery. Similarly, in Colonial physicians, home visits by rural doctors together with an array of patients, technicians and physicians routinely interacting in dispensaries and hospitals were also shown.

Building upon these formal and narrative attributes and the resultant impression that the depictions of medical technologies and facilities ultimately reflected daily routine, the description of the social dynamics taking place in the crowded facilities featured a clear-cut distinction between (medical-health) experts and non-experts. Given that the representation of medical-health practices and discourses was put across as necessary, functional and impartial, and working in harmony with the religious, educational and administrative components of the imperial effort, the classification and rationalization of distinct social groups (across race, class and gender) is depicted as essentially practical. The experts, officials and physicians - all white Spanish men - rigorously and efficiently provided immediate solutions to pressing everyday problems afflicting the non-expert patients. The "endangered" population, the non-experts, comprised native people in general, therefore establishing a clear racial differentiation between the colonizers and the colonized, in this case clearly extending across the boundary of scientific-medical knowledge production and management.

Native male patients both in Guinea and Morocco were portrayed as disturbingly docile in front of the Spanish physicians and their technologies. Particularly clear examples of this are the pleurodesis procedure performed on a patient in Ben-Karrich (Figure 1), and the description of a patient's lepromas in Mikomeseng. Not forgetting the colonizer-colonized distinction, natives were identified as members of a working-class that was duly and opportunely "helped" by the (expert) officials. The very end of Ben-Karrich gives a straightforward example, where a Moroccan patient is discharged by a Spanish physician and the commentary states that "the struggle for survival, freedom and everyday work to earn a livelihood awaits him" outside the sanatorium, where he goes "knowing what Spain has done to save him." The working class, in this case subtly identified by race, constitutes a clear beneficiary of the system, yet is effectively excluded from knowledge production and management tasks.

In Ben-Karrich, the non-expert patients in need of care were both Moroccan and Spanish women (Figure 2). The joint portrayal of these figures serves to further highlight the impartial techno-scientific imperative and rationality of the established order. Scientific-medical 


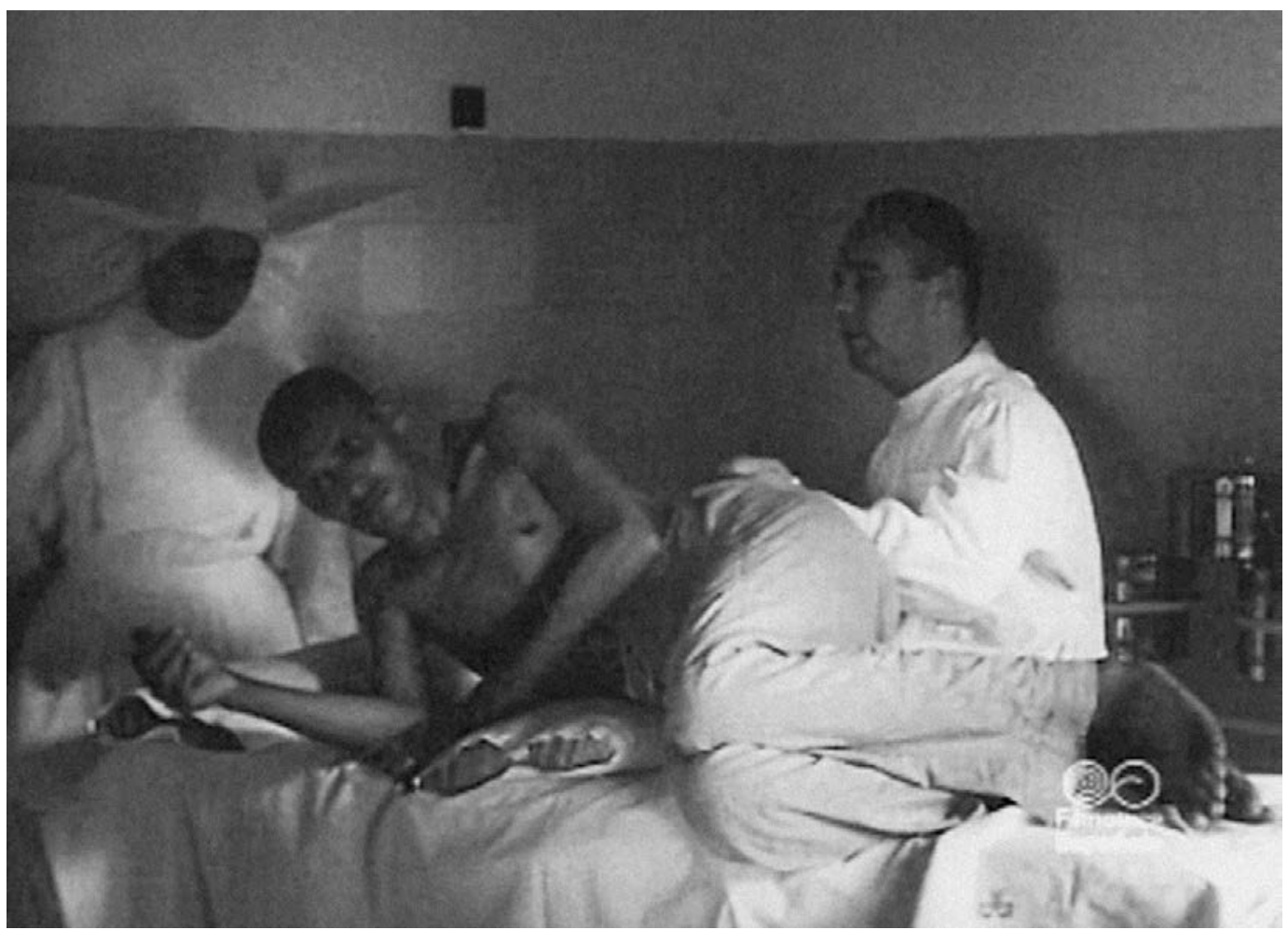

Figure 1 : "Designated patients must be taken to therapy rooms, where they are given the most suitable treatment in each case. We are going to watch the application of a pneumothorax." (Sick people at Ben-Karrich.)

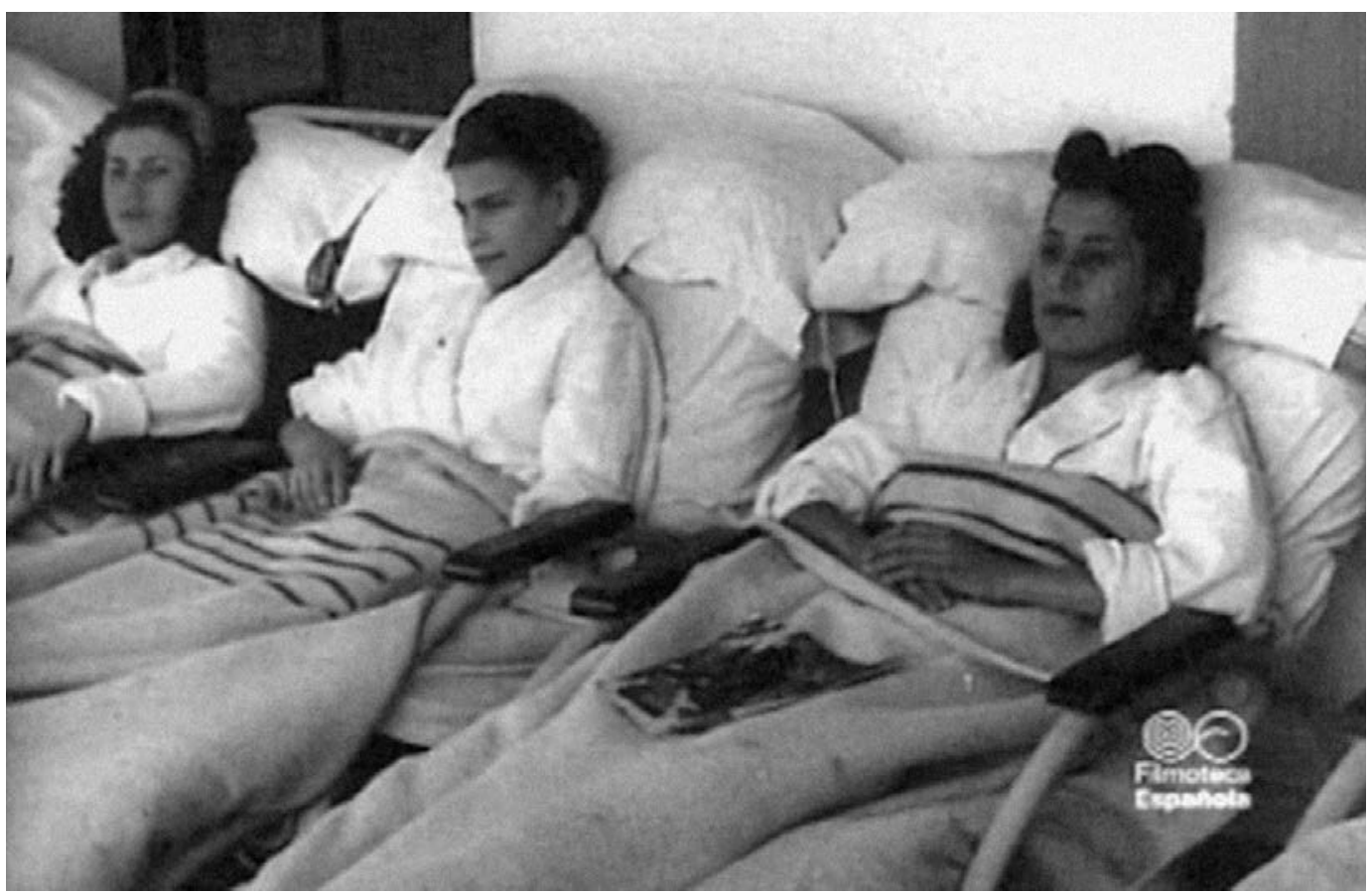

Figure 2: "Spanish and Moroccan women [are] drawn together by their shared misfortune ... if disease does not make distinctions, science does not grant privileges either." (Sick people at Ben-Karrich.) 
intervention was portrayed as a necessary response to a terrible pressing fate and as conducive to the transformation of this fate into a hopeful destiny. The commentary states that in a context where "Spanish and Moroccan women [were] drawn together by their shared misfortune ... if disease does not make distinctions, science does not grant privileges either." Moroccan women were thus effectively portrayed as full beneficiaries of the system, as were natives. Yet, at the same time, they are conspicuously excluded from the ranks of knowledge producers and managers, together with their Spanish counterparts, specifically because they were women. In this respect, it is important to note that, although the presence of Spanish male patients is mentioned in the commentary, only Moroccan male patients are shown, completely segregated from their Spanish counterparts.

The joint depiction of native and Spanish patients did not occur in the films that documented the context in Guinea. This is significant because it clearly illustrates the distinction made by different Spanish administrations, including the Franco regime, between the Spanish protectorate in Morocco and Equatorial Guinea. The colonization model in Morocco respected Islamic culture, and medical-health activities were used as a means of appealing to indigenous people in a context of geopolitical rivalry between Spain and France and avoiding the spread of epidemics across the strait. Conversely, the colonization of Equatorial Guinea was characterized by the exploitation of colonial territories and undervaluing indigenous people. Medical-health activities in Guinea were mostly concerned with avoiding the spread of tropical diseases between the colonizers and were seen as a useful way of controlling natives (Medina-Doménech, 2009). Thus, while children were barely portrayed in the films shot in Morocco, where they were supposedly looked after by their mothers, in Guinea they were depicted as a specifically "endangered group" that should be taken care of (Jiménez-Lucena, Ruiz-Somavilla, Castellano-Guerrero, 2002). Native children in Guinea (Mikomeseng) were taken away from their parents at birth to be watched over by (expert) officials (nuns and physicians), whereas Spanish children remained with their (unequivocally colonizer) mothers (Yellow fever).

The overall representation of natives in the films as non-experts in need of protection and care provided by the colonizer techno-scientific experts is reminiscent of the spirit of a "mission [that] is custodial, colonizing, albeit fraternal and full of humane sense" (General Villegas in an interview for the magazine Africa, November 1944, quoted in F.-Fígares, 2003, p.105-106). More importantly, this representation was clearly and widely portrayed to workers, peasants, and particularly women and their children. All the films mentioned the need and excellence of the Spanish civilizing drive from the medical-health point of view: "Disease retreats in the face of progress in hygiene [and] allows the conquest of inhospitable lands," in Yellow fever; the evolution from "the destitution and ignorance of the natives" to the "outstanding, current health conditions [due to] an effort that must not be ignored," in Colonial physicians; and "a social effort that must be recognized by Spaniards and Moroccans" allowing "the guaranteed presence of a Spanish physician at the head of the bed of a sick Moroccan," in Physicians in Morocco. These health systems epitomized the ideal sociocultural conditions promoted by the regime and were founded on a supposedly neutral and constitutive techno-scientific rationality. 


\section{The construction of an ideal state based on techno-scientific practices and discourses}

The sick of Mikomeseng is in effect a portrayal of the construction of a prototypical healing society in the leper colony of the same name, which is at the same time isolated. This film sums up all the main elements discussed in this paper, including the formal, didactic, commentary and narrative techniques used to adequately meet to the regime's request. The film portrays an efficient medical-health system ("Its perfect organization has achieved success") engaged in the fight against an indigenous threat (malaria, yellow fever, sleeping sickness) affecting a population in danger - the natives. It provides information using a mixture of technical and colloquial terms to talk about leprosy (identified as a "distant" threat) and its treatment. It also praises the physicians, who "carried out [their duty] with tireless zeal", along with other colonizer personnel in charge of religious and cultural education: "And just before we end, we would like to pay our modest and sincere homage to the nuns, physicians and all our fellow countrymen who in one way or another contribute to this task."

The leper colony was exemplary ("an organizational model of its kind") owing to medical-health policies and activities as well as the concomitant "religious and cultural education" ("there are a chapel and a school where [natives] receive appropriate teachings"). Although, as stated, they lived according to their customs ("the patients ... may carry on with their everyday lives ... work and farm their land as they did before in their villages") life was nevertheless crucially improved by the colonizers. This implied an unequivocal change in behavior, a staple in the media products devoted to medical-health propaganda (Jiménez-Lucena, Ruiz-Somavilla, Castellano-Guerrero, 2002; Seale, 2004). In this case, changes in native behavior were illustrated alongside medical-health and religious and cultural education activities: "[the natives] build more solid and hygienic brick houses [where] the comforts they enjoy ... are better than those they enjoyed in their former lives;" "In order to avoid the contamination of regular currency, there is a special metal currency in circulation." Behavior modification and control thus became directly linked tothe technical and organizational developments ultimately required to build, manage and shield an efficient and self-reliant state: "In this way, the leper colony in Mikomeseng is like a small independent state where all aspects of its operations are organized and planned.... Outside the grounds, the Colonial Guard keeps constant and close vigilance establishing a permanent health cordon."

Such an ideal state has to be duly sanctioned by the colonizers' scientific-medical authority. The film starts with "an inspection by the Director in Chief of the Colonial Health Services," doctor Enrique Lalinde del Río, who, incidentally, was the scientific advisor to another of the documentary films, Colonial physicians. Furthermore, this approval relied on the unrelenting monitoring of inmates by physicians ("People in the leper colony are constantly examined"). The natives portrayed in the film were submissively compliant with the experts' objective and supposedly unbiased medical directives (and, by extension, with the moral and ideological principles taught at church and school). Finally, the promise of a largely improved (healthy) future provided by the colonizers' combined religious, education and medical-health authorities was assured through the special care devoted to children, who, "Separated from their parents at birth [and] taken in under the nuns' care and the physicians' observation," 
were thus rescued "from frightening disease [so that] their bodies and souls will gradually strengthen." The documentary ends with emotionally charged images of children being fed by nuns, equating the colonial effort to "the most beautiful and humanitarian task."

With respect to social stratification, it is also interesting to note that natives are also shown crossing the (scientific-medical) knowledge production and management boundary; however under the close supervision of Spanish specialists. The film includes a detached explanation of the symptoms and treatment of leprosy blended with images of a Spanish physician supervising a native technician treating a fellow native (Figures 3 and 4):

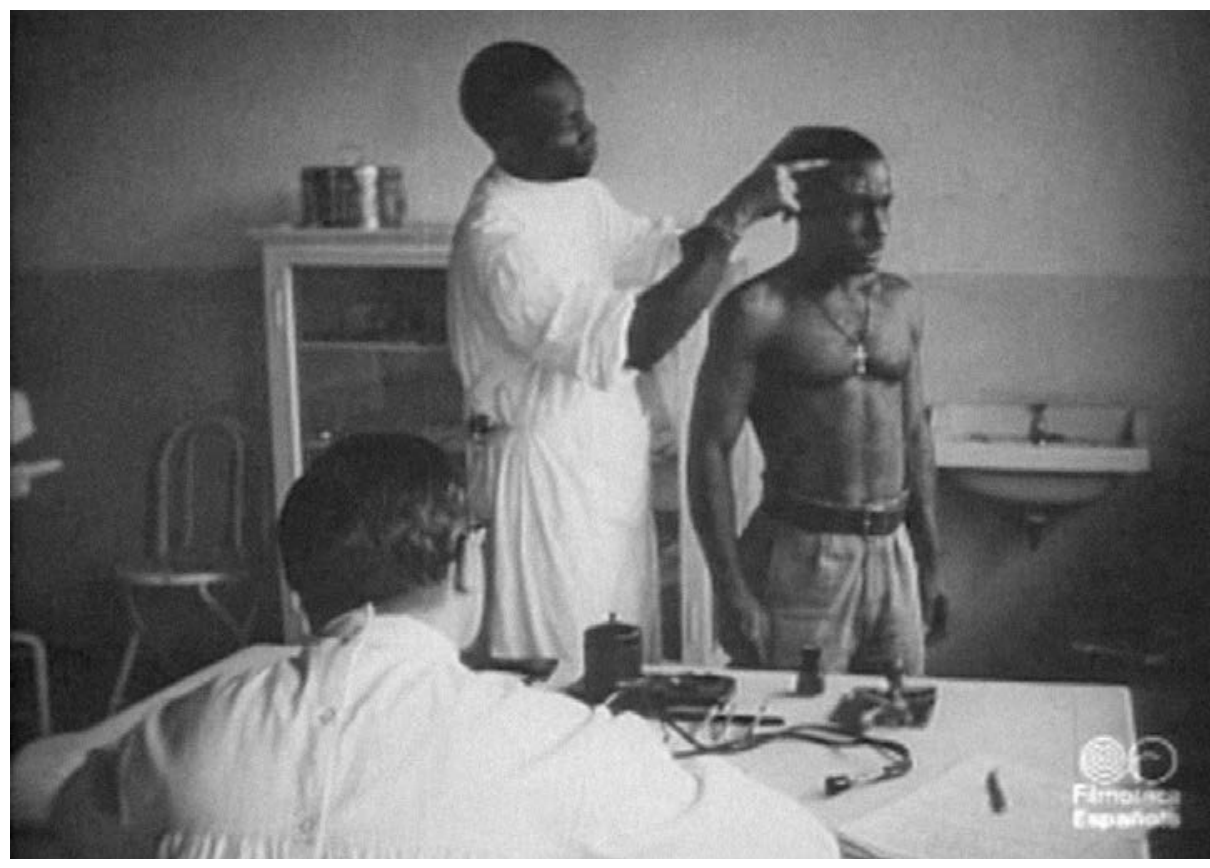

Figure 3: “Upon admission, a patient's history is monitored. Here we can see the description of lesions found in a patient by a clinical assistant." (The sick people of Mikomeseng.)

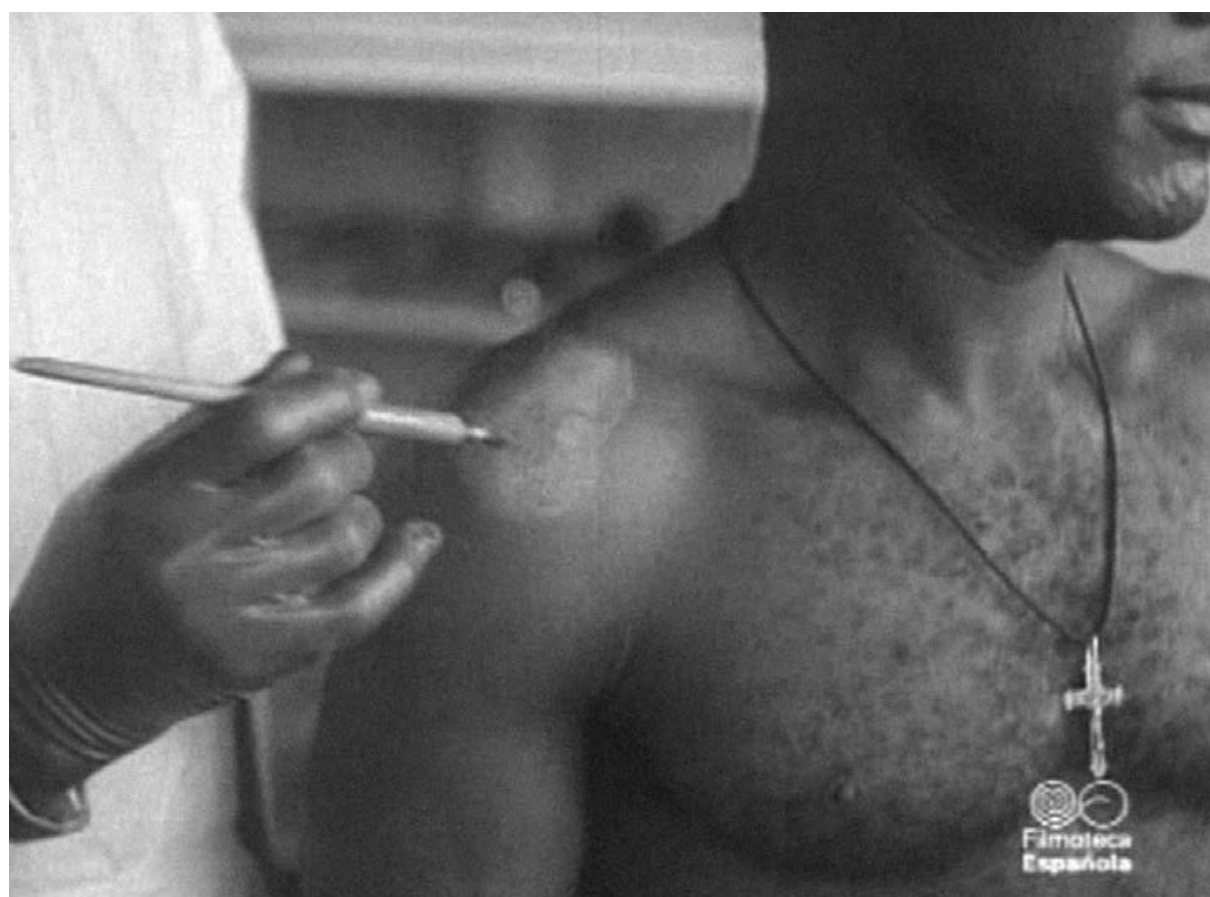

Figure 4: "With the physician's consent, the assistant tests the same patient's feeling of pain." (The sick people of Mikomeseng.) 
With the physician's consent, the assistant tests the patient's pain sensation ... Auxiliary personnel carry out this task. It is worth pointing out that all staff carrying out different tasks are chosen among natives who are less affected by this terrible disease.

In a similar way, and particularly significant for the running of the leper colony, "some patients [were also] assigned to be domestic guardsmen." Furthermore, women, another of the social groups at risk, were also featured in subaltern roles. Nuns appeared taking care of the children. Although this was by no means a minor task in the colonial venture, the nuns featured in Mikomeseng (and in the other films) were clearly depicted as, so to speak, supporting actors, since they acted upon the physicians' instructions. In this sense, it is important to highlight some additional examples involving natives and women in analogous situations in the other films: "Muslim nurses [working] with care and a cheerful demeanor" and nuns in Ben-Karrich (see Figure 1, above); "the valuable collaboration of the indigenous personnel" was mentioned and illustrated in Colonial physicians, which also featured nuns; "male nurses of the same race [as the patients]" were also shown in Physicians in Morocco, which also features nuns and native nurses, as well as nuns assisting in a surgical procedure. Remarkably, in this scene, a Spanish female technician in civilian clothing was shown handling an autoclave. These examples further confirm that women were considered a subaltern group, regardless of their birthplace, as was the case with female tuberculosis patients in Ben-Karrich.

\section{Excluding inclusion dynamics through colonial, medical-health and film practices and discourses}

The films depict medical-health practices and discourses as a set of readily consumable commodities. Direct and routine contact between physicians and patients is shown in a wide array of contexts: specialized institutions, such as the leper colony in Mikomeseng or the tuberculosis sanatorium in Ben-Karrich; hospitals and dispensaries; and even in home visits, such as in Physicians in Morocco and Colonial physicians. However, this portrayal incorporated strategic elements of socio-historical de-contextualization and techno-scientific rationalization of the population, put across through the images but also by the commentary, as we have seen. This includes the opportune substitution, from the socio-political perspective, of social class by race and, fittingly in this case, medical condition (Jiménez-Lucena, 1998; MedinaDoménench, 2009). Power relations were thus established around medicalization processes (Ballard, Elston, 2005). On the one hand, the self-denying and rigorous efforts (as explicitly qualified) of the colonizer experts and officials, whose civilizing function was defined as impartial, objective and efficient, amounted to an overtly beneficent and protective guiding undertaking. On the other, natives, workers, peasants, women and children were portrayed as a population at risk and, as such, bound to be taken care of by the colonizer experts. In this way, they were effectively included, mostly through daily expert-driven medical-health activities, as beneficiaries of the theoretical advantages that were imposed upon them allegedly to improve their living conditions.

Accordingly, colonial relationships were articulated, in practice and by the media, around the positioning of social actors in relation to knowledge producing and management processes. 
Knowledge and its legitimate producers, as arranged in everyday life and as rendered by the media, were key defining features of colonial socio-technical systems (Kusiak, 2010). However, in order to create and maintain techno-scientifically driven social stratifications "one of the most critical elements ... was the enlistment of 'colonized subjects' ... empowered as producers of 'European' knowledge but also constrained as merely 'Native' technical assistants in a system dominated by Europeans" (Kusiak, 2010, p.874-875; her emphasis). The five films analyzed in this study featured natives and women in knowledge management positions, not with standing their consideration and portrayal as risk groups in need of care and guidance, as we have just seen. However, the crossing of the knowledge production boundary by natives and women was unmistakably partial, since they continued to be subaltern medicalhealth technicians, one step closer to expert dominion, albeit closely monitored by the male colonizer authority. This further underlined functional differentiation, characterized by "the inclusion of the whole population in all societal subsystems" (Bohn, 2009, p.47). However, this level of social inclusion was granted provided that these people remained excluded from key knowledge production and management activities.

The portrayal of medical-health science and technology in these films was unequivocally paternalistic, as underscored by the commentary and by the inescapable presence of schooling and religion. This, in fact, further defined such hypothetical social inclusion dynamics as excluding. In Mikomeseng, for instance, the leper colony, depicted as a model of organization, is an obvious example of social exclusion based on avoidance and social distancing. However, the social exclusion of lepers is portrayed as being closer to controlled distancing with supervision, or including exclusion (Bohn, 2009). However, functional differentiation, where social relations are established around the multidimensional medical-health practices and discourses described above, amounts to portraying and validating an excluding inclusion strategy. Medical-health practices and discourses were not just conducive of a strategy that involved distancing through supervision, but reinforced the exclusionary nature of an unambiguous social stratification program through the plainly biased inclusion of the utterly excluded not only as beneficiaries but also as accessories to the system. This constituted an essential feature of the strategies employed to build and legitimatize a supposedly prototypical socio-political system and, moreover, conspicuously meets the nascent regime regime's need for political, ideological and cultural legitimization.

This scheme involved two additional and essential elements that are directly related to the roles of the actors involved in the making of these documentary films: the regime administrators; and filmmakers. First, the films scrupulously eschewed of any resistance on the part of the colonized due to the direct supervision of the filmmakers by the colonial administrators (Ortín, Pereiró, 2006). The films conveniently portrayed these settings as non-problematic colonial spaces, particularly when it came to medical-health policies, idealizing them regardless of whether there were any local geo-political, social and cultural problems (Mignolo, 2000; Molero-Mesa, 2003, 2006; Jiménez-Lucena, 2006). Second, the films had a distinctly didactic thrust: they used microphotography techniques, and featured cartoons and maps, and illustrated historical accounts of medical-health issues that worked not only as an introduction but also as (de)contextualizing tools. Examples include microphotography and drawings of bacilli in Mikomeseng; the introduction and 
lengthy description of laboratory techniques in Yellow fever; the introduction in Ben-Karrich; and the cartoon maps in Colonial physicians and Physicians in Morocco. These techniques emphasized the unproblematic nature of the settings portrayed by the films. Furthermore, they also expanded the excluding inclusion dynamics to the films themselves, since they aimed to be educational, supposedly becoming tools that would allow their purported viewers (in the colonies or in the metropolitan center) to access the societal subsystems they portrayed (colonial, medical-health).

In this sense, it is important to highlight that the way the films portrayed the situation was also a product of the filmmakers' genuine impressions after witnessing firsthand the regime's colonial and medical-health activities. They used documentary film techniques and conventions not only to provide a sense of truthfulness, but also to convey their own fascination and reflect the difficulties they encountered (Ortín, Pereiró, 2006). As a result, the filmmakers' interpretation was openly entertainment-driven, since the colonies provided an exotic setting, and their appreciation of the colonial effort was matched by the public's positive reception of the films. Predictably, Sanjuán's Equatorial Guinea documentary films met with instant, officially sanctioned, critical acclaim. Ignacio Mateo, national radio commentator at the time of the official premiere, "praised the importance of cinema when applied to a cultural and patriotic venture 'for reflecting and broadcasting' Spain's 'fecund civilizing effort' in those African lands" (Primer Plano 297, 23 October 1946, quoted in F.-Fígares, 2003, p.244; emphasis added). The association of the regime's civilizing drive with cultural and patriotic aims strongly suggests the necessity to translate these efforts in the colonies to the metropolitan context, in this specific case with the use of cinema.

The official press also took the opportunity to praise the objective, supposedly direct and unmodified nature of the images of documentary films, as opposed to the "purely manipulative entertainment" of (incidentally foreign-made) fiction films: "Accustomed to on screen light entertainment ... we are impressed by the realism of those naked and truthful images, devoid of shady, laboratory-made tricks" (Florentino Soria, África 56-57, AugustSeptember 1946, as quoted in F.-Fígares, 2003, p.244). In fact, deliberately combining education and entertainment in the films, rather than separating them, exemplifies a particularly useful enculturation strategy that was often employed in the official newsreels (Rodríguez-Tranche, Sánchez-Biosca, 2001; Ramírez-Martínez, 2006; Matud Juristo, maio 2008). Such combination further contributed, together with all the other elements discussed here, to the excluding inclusion dynamics by directly appealing to the viewers' emotional involvement with the abovementioned cultural and patriotic venture.

\section{Final considerations}

In this paper we have attempted to contribute to the historical understanding of the role of techno-scientific practices and discourses in shaping the Franco regime in Spain. In particular, we looked at the combined role of film and medical-health practices and discourses in the efforts made to consolidate and legitimize the regime. To do so, we adopted a multifaceted theoretical framework to analyze five Spanish medical-colonial documentary films produced during the regime's first decade, the 1940s. These films can be straightforwardly contextualized 
within the early efforts made to consolidate and legitimize the regime and its strategic interest in film, medical-health and colonial practices and discourses.

To begin with, we broadly considered science as a form of communication and set of practical everyday activities. This allowed us to focus on people's everyday lives as settings within which processes of power and the nature of authority can be examined. We also looked at film as a political instrument given its potential for presenting socio-cultural prototypes. This allowed us to consider film, specifically medical-health documentary films, as an unofficial learning space that is embedded in people's everyday lives, where meaningful processes of knowledge management occur. This approach, which considers science and media as sociopolitically significant everyday practices, afforded an analysis of the inclusion/exclusion dynamics involved in the portrayal of techno-scientifically driven social and political models of organization in given contexts.

How were scientific-medical knowledge generation and management portrayed by the films? What was the link between the way scientific-medical knowledge generation and management were depicted and the need to consolidate and legitimize the Franco regime in its early stages? Medical-health content, portrayed in unambiguous combination with the strong-handed religious and military rule enforced in the colonies, worked as a source of expert-generated and supposedly impartial certainty, cohesion and power. Science, medicine and technology were cast in their fundamental and ideological roles as tools for consolidating and legitimizing the colonial project. They were also presented as being conducive to the creation of a social order that conspicuously matched the regime's early efforts to redefine the Spanish national identity. In this respect, a very skilful combination of film techniques was adopted to serve official educational aims related to these particular films and to the overall propaganda strategy. Thus, the target audience in the colonies and metropolitan center would be witnesses to the construction and management of an exemplary and, incidentally, techno-scientifically driven social order.

What role did the actors involved (the colonizers and the colonized portrayed in the films, regime administrators, filmmakers, and target audience) in making these documentary films play? Furthermore, bearing in mind our concern with scientific knowledge management and its link with the strategies employed by the government to consolidate and legitimize the regime, what was the nature of the relationships between the different social groups that were socially, professionally and epistemologically articulated in, through and around these films. To start with, the filmmakers, working on government-commissioned films in three cases, and closely supervised by the colonial rulers in the others, efficiently used formal, didactic and narrative techniques to depict medical-health and colonial activities in a seamless blend of information, education and entertainment. Their rendition of the medical-colonial effort was overtly admiring, as was their appreciation of the regime's effort as direct witnesses and temporary members of the colonizer group. As portrayed by the films, natives, workers, peasants, women and children were positively included into the welfare system as routine beneficiaries of the progress brought about by the colonizers' science and technology, yet remained excluded from knowledge management activities.

We suggest that the films' rendering of social relations as being established around medicalhealth practices and discourses illustrates a carefully crafted excluding inclusion strategy. 
Medical-health practices and discourses were efficiently embedded into the everyday lives of colonized people, including social groups allegedly at risk (natives, workers, women and children) portrayed primarily as beneficiaries, yet evidently submissive to colonial powers. Natives and women were recurrently enlisted as subaltern medical-health technicians and as such involved in knowledge management processes and one step closer to expert dominion. However, they remained in effect accessories to the system, closely monitored by the male colonizer authority. This was part of a wider strategy to create and maintain techno-scientifically driven social stratifications in which a certain level of social inclusion was "granted" to these groups provided that they remained excluded from key knowledge management processes. Furthermore, the distinctly didactic thrust of the films and the fact that they played on the viewers' emotional involvement with the content enhanced the excluding inclusion dynamics. Viewers supposedly had access to relevant knowledge management processes, but only as spectators, and therefore clearly remained outside such processes while they were shown the possibility of contributing at the subaltern level. Thus, by openly portraying the colonized both as patients and workers and simultaneously addressing the viewers' educational and emotional aspirations, these films captured the thoroughly controlled dynamics of people's access to knowledge management processes.

Taking these aspects into consideration, it is evident that the combination of colonial rhetoric (i.e., the civilizing drive) with medical-health practices and discourses made by these films acted as a powerful socio-cultural tool for building, consolidating and legitimizing the Franco regime in its early years. The public's positive reception of the films shows that they effectively served the regime's aims with a blend of information, education, and entertainment that was much needed in post-war Spain. The movie theatre was therefore effectively an entertainment-driven science space, where people's routine communication practices were interwoven with the regime's essential socio-political needs, which in this case were conveyed through medical-health practices and discourses. These practices and discourses, as developed in the colonial settings and portrayed by the films, presented a seemingly unbiased definition of social groups according to a meticulously structured excluding inclusion strategy. At the same time, the target audiences in the metropolitan center and the colonies was effectively included in the socio-political process of building and consolidating the Franco regime, both as beneficiaries and accessories, yet unavoidably excluded and essentially deemed to be necessarily submissive spectators of associated knowledge production and management processes.

\section{ACKNOWLEDGEMENTS}

This research was supported by the Spanish Ministry of Science and Innovation, projects HAR200913389-C03-01 and HAR2009-13389-C03-03. We are particularly grateful to Trinidad del Río, from the Spanish Film Archive, and Pere Ortín, from We Are Here! Films, for their help with this research. We would also like to specially thank Simon Schaffer, Agustí Nieto-Galán, and Oliver Hochadel for their invaluable help and critical comments.

\section{NOTES}

${ }^{1}$ Filmoteca Española (Spanish Film Archive). Reference numbers, respectively: A-7549, A-9584, A-7552.

${ }^{2}$ There was another documentary in this series, titled Tse-Tse, but no copies have so far been located.

${ }^{3}$ Filmoteca Española (Spanish Film Archive). Reference numbers, respectively: A-9150, A-8820. 


\section{REFERENCES}

BALLARD, Karen; ELSTON, Mary Ann. Medicalisation: a multi-dimensional concept. Social Theory and Health, v.3, n.3, p.228-241. 2005.

BENSAUDE-VINCENT, Bernadette. A genealogy of the increasing gap between science and the public. Public Understanding of Science, v.10, n.1, p.99-113. 2001.

BOHN, Cornelia. Inclusion and exclusion: theories and findings. From exclusion from the community to including exclusion. In: Gestrich, Andreas; Raphael, Lutz; Uerlings, Herbert (Ed.). Strangers and poor people: changing patterns of inclusion and exclusion in Europe and the Mediterranean World from Classical Antiquity to the present day. Frankfurt: Peter Lang. p.35-54. 2009.

BONAH, Christian, LAUKÖTTER, Anja; CANTOR, David (Ed.).

Communicating good health: movies, medicine and the cultures of risk in the twentieth century. Geneva: Fondation Brocher. 2011.

BOON, Timothy.

Films of fact: a history of science in documentary film and television. London; New York: Wallflower Press. 2008.

BOON, Timothy.

Health educations films in Britain, 1919-29: production, genres and audiences. In: Harper, Graeme; Moor, Andrew (Ed.). Signs of life: cinema and medicine. London; New York: Wallflowers Press. p.45-57. 2005.

BRÄUCHLER, Birgit; POSTILL, John.

Theorising media and practice. Oxford; New York: Berghahn. 2010.

CAPROTTI, Federico.

Scipio Africanus: film, internal colonization and empire. Cultural geographies, v.16, n.3, p.381-401. 2009.

CASTEJÓN, Ramón; PERDIGUERO-GIL, Enrique; BALLESTER, Rosa.

Los medios de comunicación al servicio de la lucha antivenérea y la protección de la salud materno-infantil (1900-1950). História, Ciências, Saúde-Manguinhos, v.13, n.2, p.411-437. 2006.

CASTEJÓN, Ramón; PERDIGUERO-GIL, Enrique; PIQUERAS, José Luis.

Las imágenes de la salud: cartelismo sanitario en España (1910-1950). Madrid: Instituto Alicantino de Cultura "Juan Gil-Albert"/Consejo Superior de Investigaciones Científicas. 2012.
COULDRY, Nick.

Theorising media as practice. Social Semiotics, v.14, n.2, p.115-132. 2004.

COULDRY, Nick.

Review article: everyday life in cultural theory. European Journal of Communication, v.18, n.2, p.265-270. 2003.

DEL CURA, Mercedes; HUERTAS, Rafael. Alimentación y enfermedad en tiempos de hambre: España, 1937-1947. Madrid: CSIC. 2007.

ELENA, Alberto.

Spanish colonial cinema: contours and singularities. Journal of Film Preservation, v.63, n.63, p.29-35. 2001.

ELLWOOD, Sheelagh.

Spanish newsreels 1943-1973: the image of the Franco regime. Historical Journal of Film, Radio and Television, v.7, n.3, p.225-238. 1987.

F.-FÍGARES, María Dolores. La colonización del imaginario: imágenes de África. Granada: Universidad de Granada. 2003.

FLORENSA, Clara; HOCHADEL, Oliver; TABERNERO, Carlos.

Science on television: audiences, markets and authority. Some conclusions. Actes d'Història de la Ciència i de la Tècnica, v.7, p.127-136. 2014.

FOUCAULT, Michel.

Historia de la sexualidad, 1: la voluntad de saber. Madrid: Siglo XXI. 2005.

FOUCAULT, Michel.

Vigilar y castigar. Madrid: Siglo XXI. 1982.

GIDDENS, Anthony.

The constitution of society. Cambridge: Polity Press. 1984.

HORST, Maja; MICHAEL, Mike.

On the shoulders of idiots: re-thinking science communication as "event". Science as Culture, v.20, n.3, p.283-306. 2011.

IRWIN, Alan; WYNNE, Brian.

Misunderstanding science? The public

reconstruction of science and technology.

Cambridge: Cambridge University Press. 1996.

JIMÉNEZ-LUCENA, Isabel.

Differences, paradoxes and exclusions regarding abortion. A possible interpretation of A Story of Women and Vera Drake. Journal of Medicine and Movies, v.7, n.2, p.61-68. 2011.

JIMÉNEZ-LUCENA, Isabel.

Gender and coloniality: the "Moroccan woman" and the "Spanish woman" in Spain's sanitary 
policies in Morocco. História, Ciências, Saúde Manguinhos, v.13, n.2, p.325-347. 2006.

JIMÉNEZ-LUCENA, Isabel.

Medicina social, racismo y discurso de la desigualdad en el primer franquismo. In: Huertas, Rafael; Ortiz, Carmen (Ed.). Ciencia y fascismo. Madrid: Doce Calles. p.111-126. 1998.

JIMÉNEZ-LUCENA, Isabel.

El tifus exantemático en la posguerra española (1939-1943): el uso de una enfermedad colectiva en la legitimación del "Nuevo Estado". Dynamis, v.14, p.185-198. 1994.

JIMÉNEZ-LUCENA, Isabel; MOLERO-MESA, Jorge.

Good birth and good living: the (de)medicalizing key to sexual reform in the anarchist media of inter-war Spain. International Journal of Iberian Studies, v.24, n.3, p.219-241. 2011.

JIMÉNEZ-LUCENA, Isabel; RUIZ-SOMAVILLA, Maria José; CASTELLANOS-GUERRERO, Jesús. Un discurso sanitario para un proyecto político: la educación sanitaria en los medios de comunicación de masas durante el primer franquismo. Asclepio, v.54, n.1, p.201-218. 2002.

KIRBY, David.

The future is now: diegetic prototypes and the role of popular films in generating real-world technological development. Social Studies of Science, v.40, n.1, p.41-70. 2010.

KIRBY, David.

Hollywood knowledge: communication between scientific and entertainment cultures. In: Cheng, Donghong et al. (Ed.). Communicating science in social contexts. New York: Springer. p.165-181. 2008.

KUSIAK, Pauline.

Instrumentalized rationality, cross-cultural mediators, and civil epistemologies of late colonialism. Social Studies of Science, v.40, n.6, p.871-902. 2010.

LUHMANN, Niklas.

Inclusión-exclusión. In: Luhmann, Niklas. Complejidad y modernidad: de la unidad a la diferencia. Madrid: Trotta. p.167-195. 1998.

LYNCH, Lisa L.

Arrowsmith goes native: medicine and empire in fiction and film. Mosaic, v.33, n.4, p.193-208. 2000.

MACKENZIE, John M.

Propaganda and empire: the manipulation of British public opinión, 1880-1960. Manchester: Manchester University Press. 1986.
MATUD JURISTO, Álvaro.

La incorporación del cine documental al proyecto del NO-DO. Historia y Comunicación Social, v.13, p.105-118. may 2008.

MEDINA-DOMÉNECH, Rosa Maria. Scientific technologies of national identity as colonial legacies: extracting the Spanish nation from Equatorial Guinea. Social Studies of Science, v.39, n.1, p.81-112. 2009.

MEDINA-DOMÉNECH, Rosa Maria. Paludismo, explotación y racismo científico en Guinea Ecuatorial. In: Rodríguez-Ocaña, Esteban et al. (Ed.). La acción médico-social contra el paludismo en la España metropolitana y colonial. Madrid: CSIC. p.381-427. 2003.

MEDINA-DOMÉNECH, Rosa Maria; MENÉNDEZNAVARRO, Alfredo.

Cinematic representations of medical technologies in the Spanish official newsreel, 1943-1970. Public Understanding of Science, v.14, n.4, p.393-408. 2005.

MEMMI, Albert.

Decolonization and the decolonized. Boston: Beacon Press. 1991.

MIGNOLO, Walter D.

Local histories/global designs: coloniality, subaltern knowledges and border thinking. Princeton: Princeton University Press. 2000.

MOLERO-MESA, Jorge.

From master bleeder to European physician: medicine, science, and colonial difference in the Spanish Protectorate in Morocco (1912-1956). História, Ciências, Saúde - Manguinhos, v.13, n.2, p.375-392. 2006.

MOLERO-MESA, Jorge.

Militares, moros y mosquitos: el paludismo en el protectorado español en Marruecos (19121956). In: Rodríguez-Ocaña, Esteban et al. (Ed.). La acción medico-social contra el paludismo en la España metropolitana y colonial. Madrid: CSIC. p.323-380. 2003.

MOLERO-MESA, Jorge.

Health and public policy in Spain during the early Francoist regime (1936-1951): the tuberculosis problem. In: Löwy, Ilana; Krige, John (Ed.). Images of disease: science, public policy and health in post-war Europe. Luxembourg: Office for Official Publications of the European Communities. p.141-161. 2001.

MOLERO-MESA, Jorge.

Enfermedad y previsión social en España durante el primer franquismo (1936-1951): el frustrado seguro obligatorio contra la tuberculosis. Dynamis, v.14, p.199-225. 1994. 
MOLERO-MESA, Jorge; JIMÉNEZ-LUCENA, Isabel.

Arm and brain: inclusion-exclusion dynamics related to medical professional within Spanish anarcho-syndicalism in the first third of the 20th century. Dynamis, v.33, n.1, p.19-41. 2013.

MONTERDE, José Enrique.

El cine de la autarquía (1939-1950). In: Gubern, Román (Ed.). Historia del cine español. Madrid: Cátedra. p.181-238. 2004.

NIETO-GALÁN, Agustí.

Los públicos de la ciencia: expertos y profanos a través de la historia. Madrid: Marcial Pons. 2011.

ORTÍN, Pere; PEREIRÓ, Vic.

Mbini: cazadores de imágenes en la Guinea colonial. Barcelona: Altair; WAHF. 2006.

OSTHERR, Kirsten.

Medical visions: producing the patient through film, television and imaging technologies. Oxford: Oxford University Press. 2013.

PERDIGUERO, Enrique; BALLESTER, Rosa; CASTEJÓN, Ramón.

Films in Spanish health education: the case of child health (1928-1936). Higyea Internationalis, v.6, n.2, p.69-97. 2007.

PRESTON, Paul.

Franco: a biography. New York: Basic Books; Harper Collins. 1994.

RAMÍREZ-MARTÍNEZ, Felipe. E.

Ciencia, tecnología y propaganda: el NO-DO, un instrumento de popularización de la ciencia al servicio del Estado (1943-1957). In: Ordóñez, Javier (Ed.). El pensamiento científico en la sociedad actual. Madrid: MEC. p.253-261. 2006.

RAWAL, Nabin.

Social inclusion and exclusion: a review. Dhaulagiri Journal of Sociology and Anthropology, v.2, p.161-180. 2008.

REEVES, Nicholas.

The power of film propaganda: myth or reality. New York: Continuum. 1999.

REICH, Jacqueline; GAROFALO, Piero (Ed.). Re-viewing fascism: Italian cinema, 1922-1943. Bloomington: Indiana University Press. 2002.

RODRÍGUEZ-TRANCHE, Rafael; SÁNCHEZBIOSCA, Vicente.

NO-DO, el tiempo y la memoria. Madrid: Cátedra/ Filmoteca Española. 2001.
SEALE, Clive.

Media and health. London: Sage. 2004.

SECORD, James A.

Knowledge in transit. Isis, v.95, n.4, p.654-672. 2004.

STANARD, Matthew G.

Interwar pro-empire propaganda and European colonial culture: toward a comparative research agenda. Journal of Contemporary History, v.44, n.1, p.27-48. 2009.

TABERNERO, Carlos; JIMÉNEZ-LUCENA, Isabel; MOLERO-MESA, Jorge.

Libertarian movement and self-management of knowledge in the Spain of the first third of the 20th century: "Questions and answers" section (1930-1937). Estudios. Dynamis, v.33, n.1, p.4367. 2013.

TABERNERO, Carlos; JIMÉNEZ-LUCENA, Isabel; MOLERO-MESA, Jorge.

Scientific-medical knowledge management through media communication practices: a review of two opposite models in early 20th century Spain. Journal of History of Science and Technology, v.6, p.64-84. 2012.

TABERNERO, Carlos; PERDIGUERO, Enrique. Cine y medicina: imágenes sobre la salud y la enfermedad. In: Brigidi, Serena (Ed.). Cultura, salud y cine. Tarragona: Publicacions URV. 2015.

TABERNERO, Carlos; PERDIGUERO, Enrique. Cinema and the collective dimensions of disease. Journal of Medicine and Movies, v.7, n.2, p.44-53. 2011.

TABERNERO, Carlos et al. Media practices, connected lives. In: Cardoso, Gustavo; Cheong, Angus; Cole, Jeffrey (Ed.). World wide internet: changing societies, economies and cultures. Macau: University of Macau. p.331-355. 2009.

TAIBO, Paco Ignacio.

Un cine para un imperio: películas en la España de Franco. Madrid: Oberon. 2002.

THOMPSON, John B.

The media and modernity: a social theory of media. Cambridge: Polity Press. 1995.

TOPHAM, Jonathan R. (Ed.).

Focus: historicizing "popular science". Isis, v.100, n.2, p.310-368. 2009.

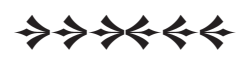

